\title{
Shopick - Shop for Ease
}

\author{
Ayesha Anees Zaveri \\ University of Kuala Lumpur \\ Kuala Lumpur, Malaysia \\ zaveri.ayesha@s.unikl.edu.my

\begin{abstract}
Muhammad Mansoor Alam
Universiti Kuala Lumpur,

Kualalumpur, Malaysia

mansoor@unikl.edu.my
\end{abstract} \\ Saba Imtiaz \\ Bahria University \\ Karachi, Pakistan \\ sabaimtiaz.bukc@bahria.edu.pk
}

\author{
Mobeen Nazar \\ University of Kuala Lumpur \\ Kuala Lumpur, Malaysia \\ mobeen.nazar@s.unikl.edu.my \\ Eiad Yafi \\ Institute of Business \\ Dili, Timor-Leste \\ eiad.yafi@uts.edu.au \\ Saba Akhter \\ Bahria University \\ Karachi, Pakistan \\ sabaakhter88@hotmail.com
}

\author{
Nabiha Faisal \\ Bahria University \\ Karachi, Pakistan \\ nabihafaisal.bukc@bahria.edu.pk \\ Sarama Shehmir \\ Ryerson University \\ Ontario, Canada \\ sarama.shehmir@ryerson.ca \\ Dr. Mazliham Mohammad Su'ud \\ Universiti Kuala Lumpur, \\ Kuala Lumpur, Malaysia. \\ mazliham@unikl.edu.my
}

\begin{abstract}
According to findings made during a survey performed at malls, consumers have difficulty determining their best preferences and requirements while shopping. Local marketers confront several obstacles. They don't have access to a platform that may aid in the expansion and growth of their sales and business. Following this statistic, Shopick was created, which would be beneficial to both customers and suppliers.
\end{abstract}

Keywords-E-Commerce, Digital Marketing, Online Shopping, Brands, Trends, Digital Communication, Marketing Strategy, Marketing Budget, Local Business, Advertising, Social Media and Geolocation.

\section{INTRODUCTION}

The prime motive for developing Shopick is to provide a platform that overcomes any interruption between the neighborhood, advertisers, and consumers. Some correlated work has already been done by a few applications and associated websites, but our fundamental concern and aim audience are the local brands. They have to first register themselves in the application and then upload their items or products to view them easily. The customers will be allowed to give feedback and rate the respective product, so other patrons will be aware of the quality, and on the other hand, the business owner will be acknowledged about the sales of his products. It will also benefit the consumers to let them know about the product of their need and requirements, closest to their desired location. It will help the local vendors to promote their business through Shopick. This will also help the customers by saving their valuable time and providing them with a platform that will make their lives easier and faster. The issue which the neighborhood advertisers or local marketers face is to nurture their business domestically. They don't have enough resources to lift their business on an extensive scale. However, they manage to have a Facebook page or an Instagram business account, but due to lack of resources and finance, they cannot reach the organic audience. For this main reason, Shopick provides flexible procedures through item seek. Similarly, clients arise that the central issue of finding their item must be close to their home. Shopick will overcome this barrier between the neighborhood advertisers and the clients through viable business profiles of every marketer with designated item profiles. The clients will have their profiles to look for their item closest to their district.

\section{BACKGROUND}

Since individuals are facing inconveniency in finding the stuff of their needs in the market, and we observed this hindrance in our survey to the malls. In the meantime, the neighborhood advertisers don't have a stage that could help them grow their business. Some related work has already been done by a few renowned applications, and few associated sites exist too; however, our main aim is to target are the nearby brands locally available. They will initially enlist the items and then will upload the items with their details. The clients will be permitted to give input and ratings, so upcoming clients can become familiar with the nature of the product, and the marketer would become aware of which of their items are mostly sold and can also keep track of the sales of the products.

\section{LITERATURE REVIEW}

E-commerce has now categorically become an domineering part of our culture and society. Internet is and will have an excessive part in our day-to-day lives. It is subsequently critical that small businesses have their own to keep in competition with the larger websites.[2] Through e- commerce, the exchange of information associated with buying and selling will be faster. The compensations of e- commerce are cost reserves, betterquality, efficiency, and customization. To comprehend electronic commerce, it is vital to organize the unrelated terms that are used and to assess their foundation, cause, and procedure. [1] 
The development of new information and communication technologies, chiefly the Internet and social networks or media, has altered marketing aspects and procedures and increasing the influence of consumers. [6] The Internet- and online-based social media have transformed consumer consumption conducts by providing consumers with new habits of observing for, measuring, selecting, and purchasing goods and services. [4]

These expansions impact how dealers and marketers function and touch advertising and promoting practices in terms of both plans, policy, and strategies by offering marketers new encounters and tough adoptions. [20] Social media have provided new beginnings and chances for customers to involve in social association and communication on the world wide web [5].

Patrons practice social media, such as online groups and pages, to create content and to shape their link with other active users vigorously. The knowledge of social media can also label the recompenses to be grown by the business. [15]

Existing expansions on the net and the progression of social media have shortened the association of consumers. Consumers have social communication through social media such as online means, pages, forums, groups, communities, evaluations, appraisals, and endorsements. [9]

These extensions have familiarized a new stream in ecommerce, which allows consumers to produce content and inspire others. These interactions offer diverse standards and values for both business owners and consumers. [13] Online shopping states to the current inclinations of being able to buy everything from home with a single click.

The emphasis is on key variables that were consequent from the study. [17] These variables are trust, time, product variety, convenience, and privacy, which regulate how consumer- buying performance is reflecting online shopping movements. [18]

The use of social media, mobile applications, online transaction, and other sorts of digital communication technologies include Sites, Purchasing and Marketing Online, Smartphones, Digital TVs, Video Streaming, eBooks, Digital Music, Geolocation, Blogs, and Social Media, has now become a part of nearly every person's life and routine. Every next being has a smartphone these days. [20] The number of active internet users has already crossed over 2 billion people.
Facebook alone has nearly 1 billion active users per day. The increasing number of social media applications are attracting and fascinating people towards them. [3] People are now more exposed to digital and social media. The ease of access to things has been significantly and momentously transfigured and revolutionized by the current era of digitalization. [14]

Customers or Consumers now search for information about the producers, products, purchase and then consume them and add their reviews about that specific product; also, they rate the producer and product. On the other hand, the dealers have responded to this ultimate change using digital marketing channels and platforms.

Almost one-third of global advertising and marketing spending is done through digital marketing, making it very important to understand and examine the consumer's behavior in the digital marketing environment. Digital advertising has become a fundamental matter of study and learning in this field regarding consumer behavior. It emphasizes the detail of how consumers act and behave towards digital advertisement from various perspectives and outlooks. Different studies and practices are approved to study the customer's preference and fondness for multiple products.

One of the most common methods is personalized and modified recommendations based on web browsing history and the use of cookies to save the user's information and data and keep a log that how the user navigated through the products on the website.

There are many kinds of deals, promotions, and coupons that are appearing as pop-ups, and they sometimes deviate the shopper from their planned and strategic shopping paths and can increase unintended expenditure. But on the other hand, many consumers don't have enough time to go physically to buy a product and prefer digital use for their comfort and ease. There's a lot of future in digital marketing which will continue to grow in the coming years.

So, more research would lead to a better understanding of consumers and marketers. The digital market is so competent that even a small business owner uses it to expand the business.

Almost all the particulars and details are present for any product of user's choice on the internet, and shipping methodologies and options have also been made fairly good for safe and smooth delivery at the door step. 


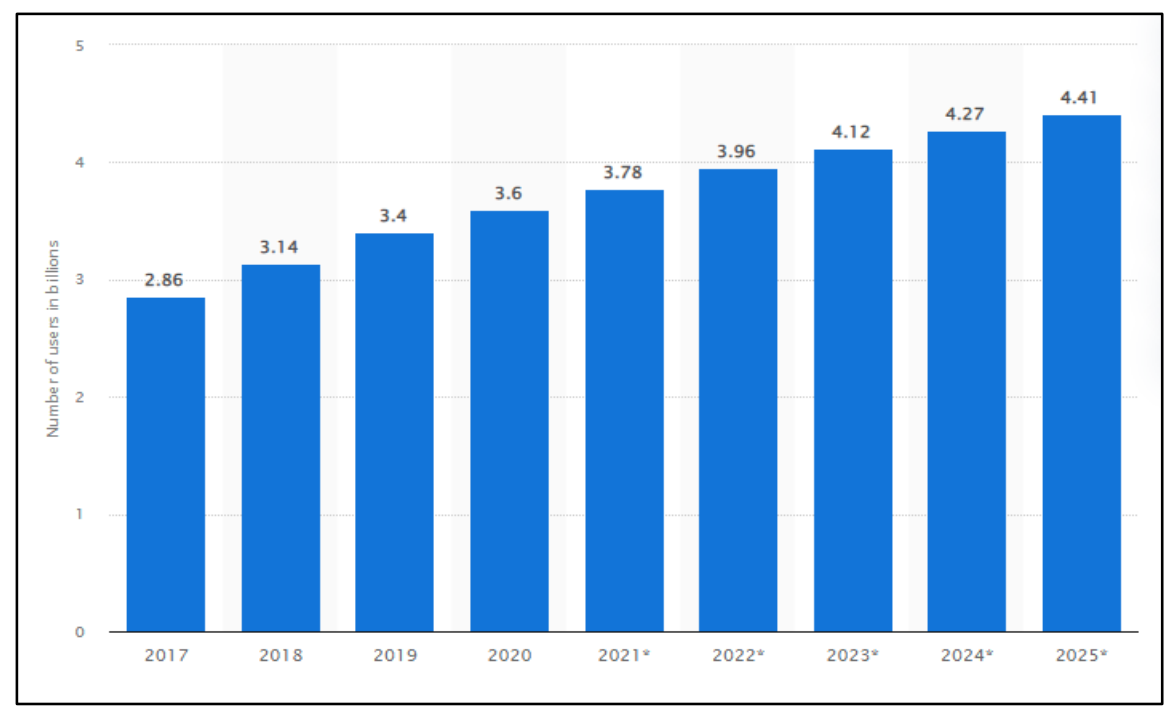

Fig. 1 Number of social network users worldwide from 2017 to 2025 (in billions)

Table 1 Business Name

\begin{tabular}{|c|}
\hline Makeup Studio \\
\hline F F Fashion \\
\hline Rising Communication \\
\hline Desire \\
\hline Fast Communication \\
\hline Trendz \\
\hline Bags and Bags \\
\hline BA Clothing \\
\hline Libaas Lawn \\
\hline Khareed Lo \\
\hline Nazeer Cosmetics \\
\hline
\end{tabular}

\section{PROBLEM STATEMENT}

The utilization and application of internet-based life, multipurpose applications, web-based retailing, and other computerized correspondence innovations have become vital in every individual's life. Consistently, individuals now possess an advanced and latest mobile phone these days. The extent of dynamic web clients has effectively and efficiently crossed 2 billion people. Facebook alone has about 1 billion emotive and active clients every day. The increasing number of internet-based life applications is attracting a wide range of the population towards itself. People are now gradually introduced to advanced and web-based life. The simple introduction to them has been immensely changed by the web time, the computerized and online network promoting and marketing. Digital marketing is a process in which people buy items or products online. Our application highlights are that of the local marketers, i.e., how they can expand their business without many resources. The application also gives the customers information regarding fetching the details of the product that is nearest to their location. This application aims to "Bridging the gap between the local marketers and the customers." These are some of the problems and glitches faced by the local business owners and the customers. That is listed as follows:
a. Marketing/Advertisement Budget
b. Focus on Local Marketers
c. Maintainable Product Profile
d. Access to nearby markets
e. Convenience of consumer which includes Quality, Locality, and Affordability




\section{ANALYSIS}

A short survey was taken from both parties, and the results are as follows: Basically, we initiated the requirements to gather one of the leading and significant sub-phases of analysis through a survey conducted at the nearest malls. It made clear the business owners' view about the local market and the customers who shop around. A few screenshots are attached below, which have been extracted from the survey. According to the surveys shown in figure 3, most of the local marketers, i.e. $(45.5 \%)$, deal in the clothing category with a few in shoes and bags $(9.1 \%)$, mobile (18.2\%), cosmetics (27.3\%), etc.

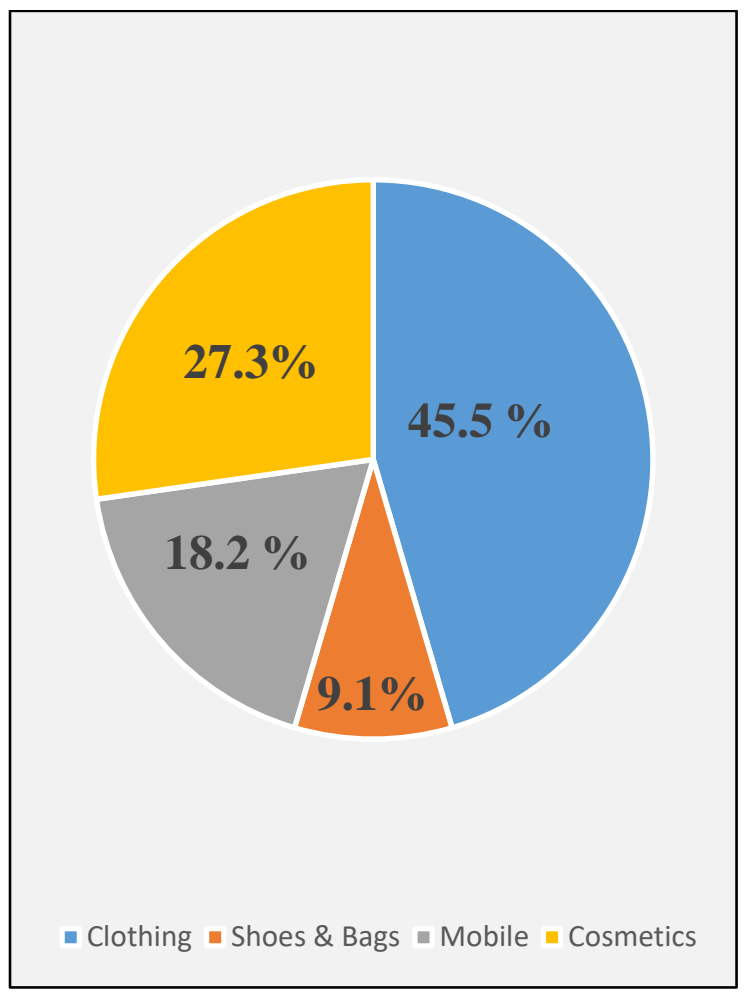

Fig. 2 Category

Another essential survey question about budgeting shown in the figure 4 revealed that only $18.2 \%$ of the local marketers have a separate budget allocated for their promotions and marketing, and the rest, $81.8 \%$, do not keep an individual budget for their publicity and marketing.

According to our survey, most local business owners, almost $81.8 \%$, don't keep a separate marketing budget, and very few keep a marketing budget according to their business scale.

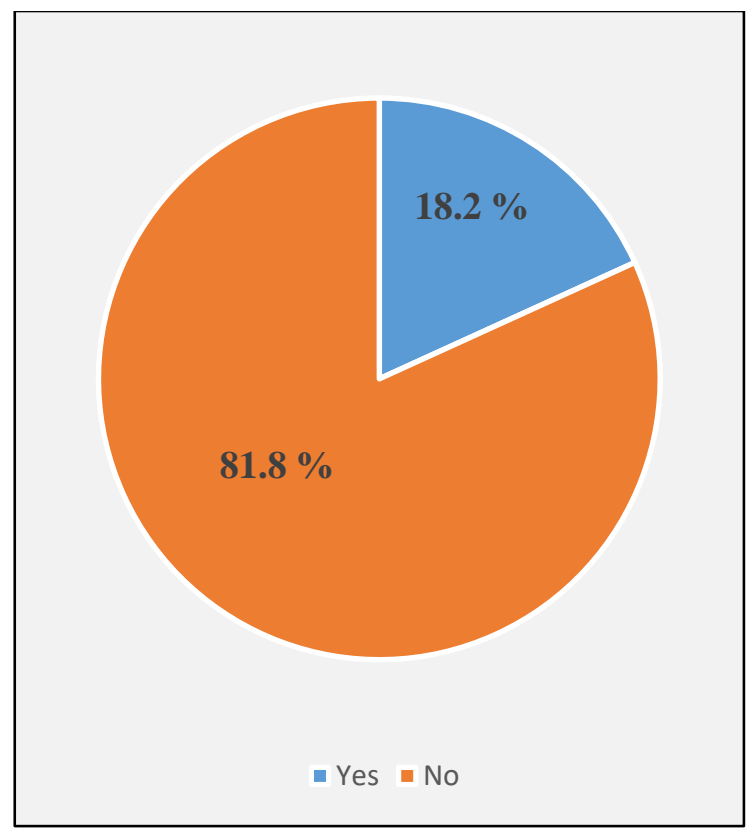

Fig. 3 Separate Marketing Budget

Figure 4 reveals about the surey results regaring the monthly marketing budget.

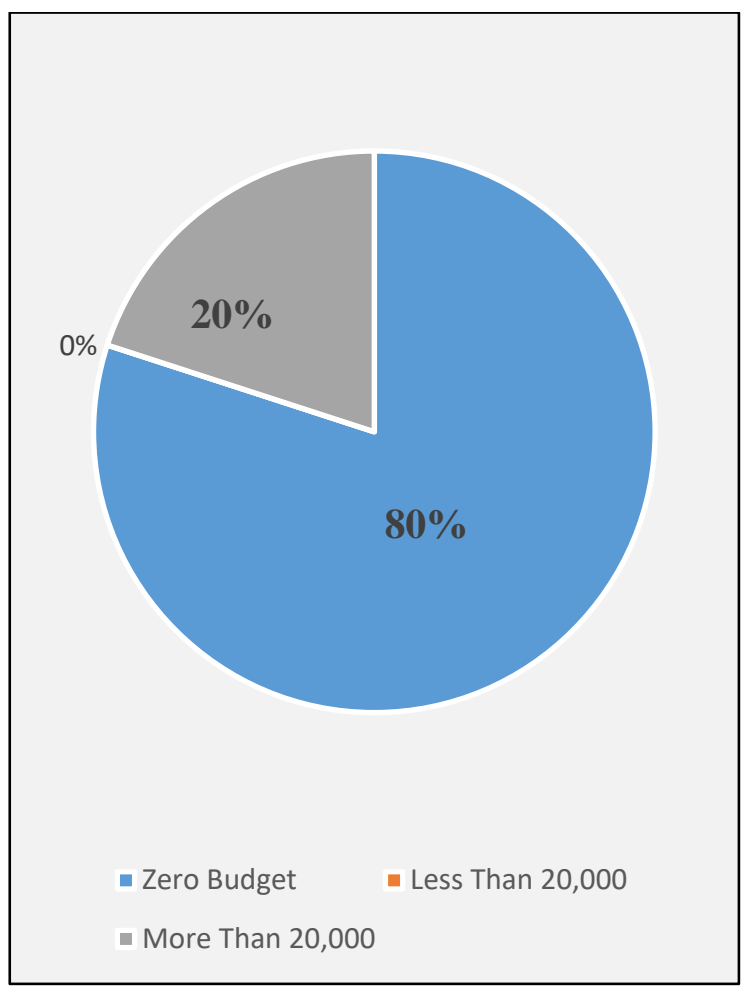

Fig. 4 Monthly Marketing Budget

Figure 5 shows about the survey results regarding methods of advertising. 


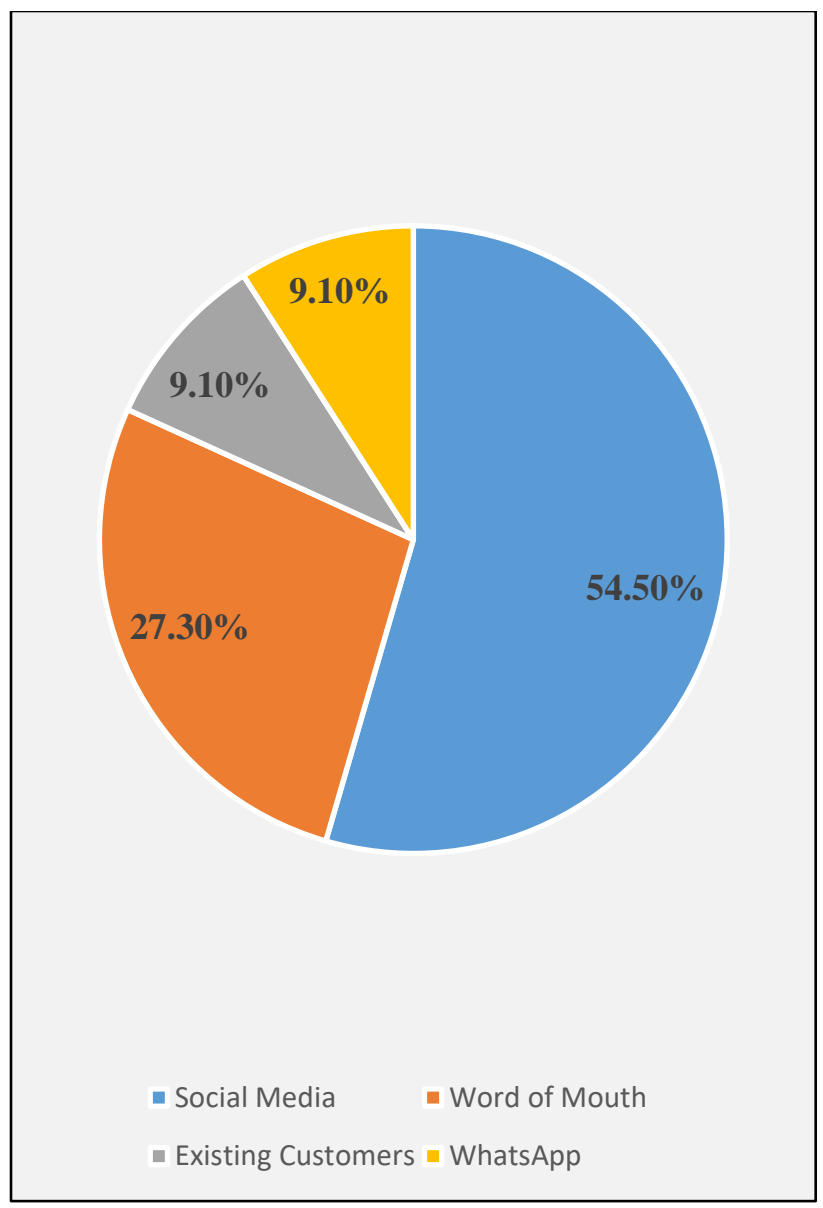

Fig. 5 Methods of Advertising

Most local marketers use social media, i.e., Facebook, Instagram, as their primary means of marketing and promotions.

Word of Mouth is used. And a few marketers market through their existing customers and warm contacts, i.e., WhatsApp.

The majority of the local marketers, i.e., $63.6 \%$, as shown in the figure 6 believed that their current marketing method is not sufficient and operative in scaling up their business and that they need an application that would provide them with a platform to gear up and boost their local business.

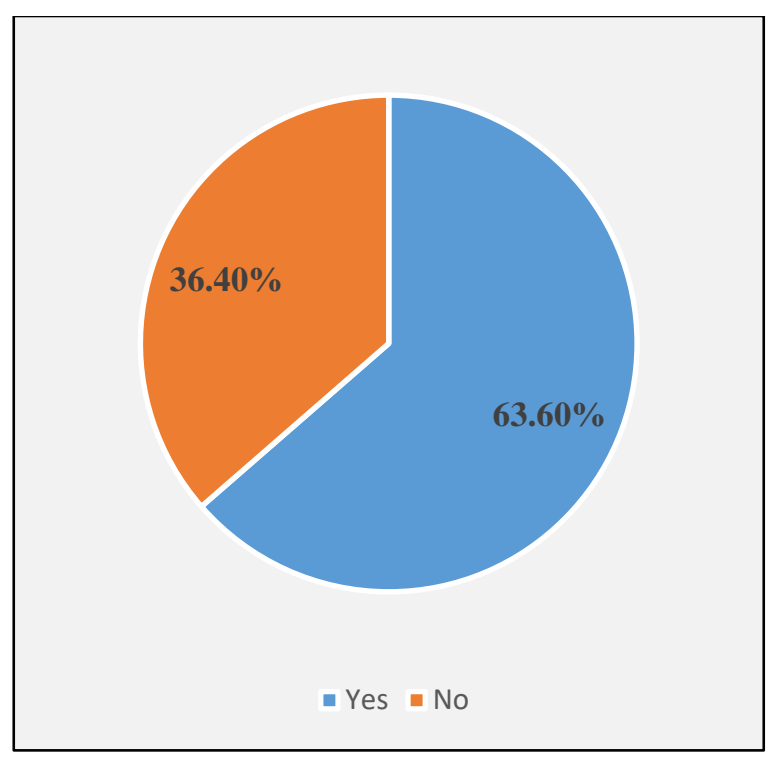

Fig. 6 Effectiveness of current marketing strategy

According to the results of a survey question from the responders about possessing of smart phones, as the shown in the figure 7, the answer was 100 percent 'Yes'.

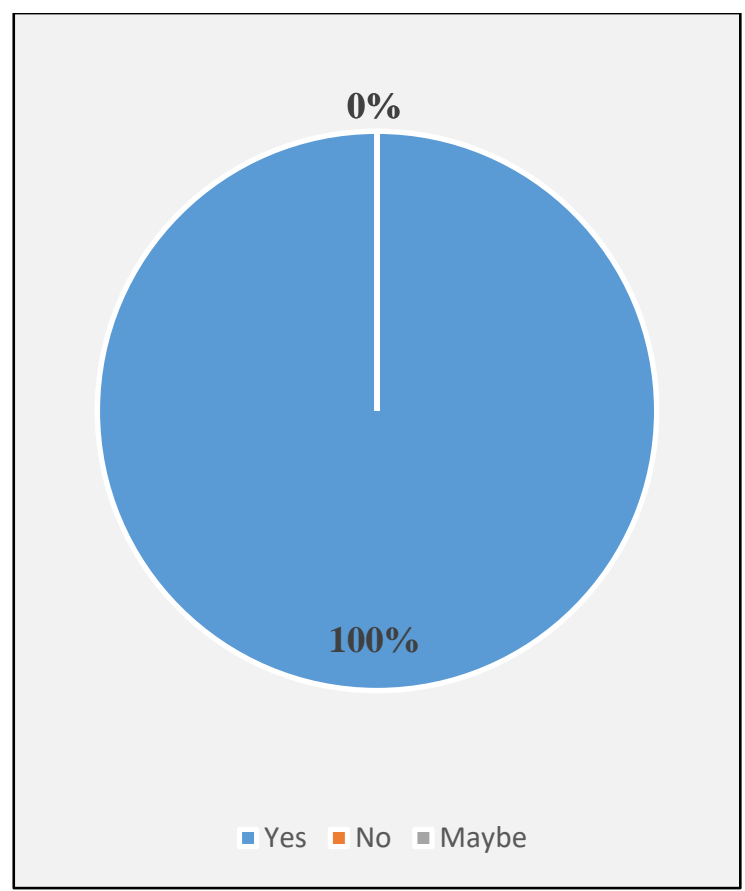

Fig. 7 Usage of Mobile Phones

\section{COMPARATIVE ANALYSIS}

Comparative Analysis of conducted research is listed in the table 2 . 
Table 2 Comparative Analysis of conducted research

\begin{tabular}{|c|c|c|c|}
\hline & Daraz.pk & Kaymu.pk & Shopick \\
\hline Business Model & $\begin{array}{l}\text { Works on the B2C model } \\
\text { effectively }\end{array}$ & $\begin{array}{l}\text { Works generally on B2C } \\
\text { and } \mathrm{C} 2 \mathrm{C} \text { models. However, } \\
\text { started to opt B2B model for } \\
\text { selected products }\end{array}$ & $\begin{array}{l}\text { Designed for B2C models } \\
\text { purely }\end{array}$ \\
\hline Wholesaling & $\begin{array}{l}100 \% \text { wholesaling of all } \\
\text { products }\end{array}$ & $\begin{array}{l}80 \% \text { wholesaling of all } \\
\text { products based on season } \\
\text { promotions }\end{array}$ & $\begin{array}{l}\text { Both wholesaling and non- } \\
\text { wholesaling products based }\end{array}$ \\
\hline Drop shipping & $\begin{array}{l}\text { Drop shipping as per target } \\
\text { area }\end{array}$ & $\begin{array}{l}\text { Drop shipping as per target } \\
\text { area }\end{array}$ & $\begin{array}{l}\text { No Drop shipping as } \\
\text { product is purchased in } \\
\text { person }\end{array}$ \\
\hline Model of Search & Open searches & Open searches & Vicinity based searches \\
\hline Product Category & $\begin{array}{l}\text { All types of products } \\
\text { covered }\end{array}$ & Mainly Clothing & $\begin{array}{l}\text { Clothing, Cosmetics, } \\
\text { Jewelry, Communication }\end{array}$ \\
\hline
\end{tabular}

\section{DESIGN}

This section consists of the designs of the overall system, including UML diagrams.

\section{A. Basic Workflow}

The Figure 8 below shows how the application will work and how an end customer and local marketer would interact through the product search.

The customer will search for a product of his choice, and the searched products will appear to have a brief detail about the product.

Upon clicking the product, it would direct the customer to the product profile, maintained and sustained by a specific business owner. If a customer clicks on the business name, it would then lead him to the business owner's profile, where all of his products would be shown along with the ratings and previous comments of customers who have previously shopped from that and the reviews.

The direction and ETA (Estimated Time of Arrival) for each shop would be shown to ease the customer.

On the other hand, the business owner can maintain his business profile by accumulating, editing, and removing the products. He will receive a notification if a customer has contacted him.

Additionally, he would have data analytics for his business to let him know which of his products are sold most often and let him know the ratings and reviews he is attaining. 


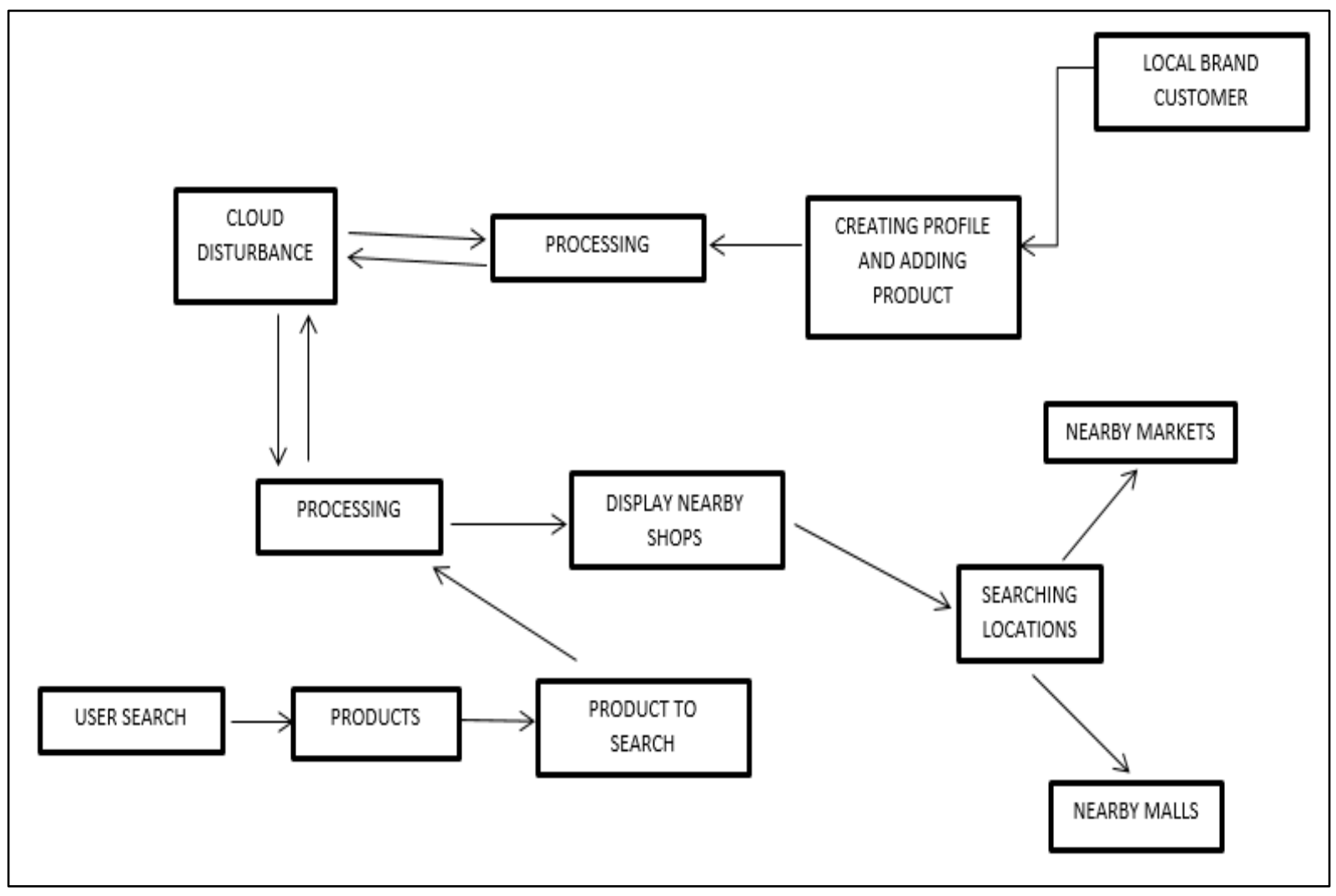

Fig. 8 Basic Workflow

\section{B. System Context Diagram}

System context in Figure 9 display a system as a complete and its involvements, inputs and outputs from/to external features. System Context Diagram signifies all external units that may interact with a system; the system context diagram's objective is to emphasis on exterior aspects and measures that should be considered in emerging a complete set of systems requirements and constraints.

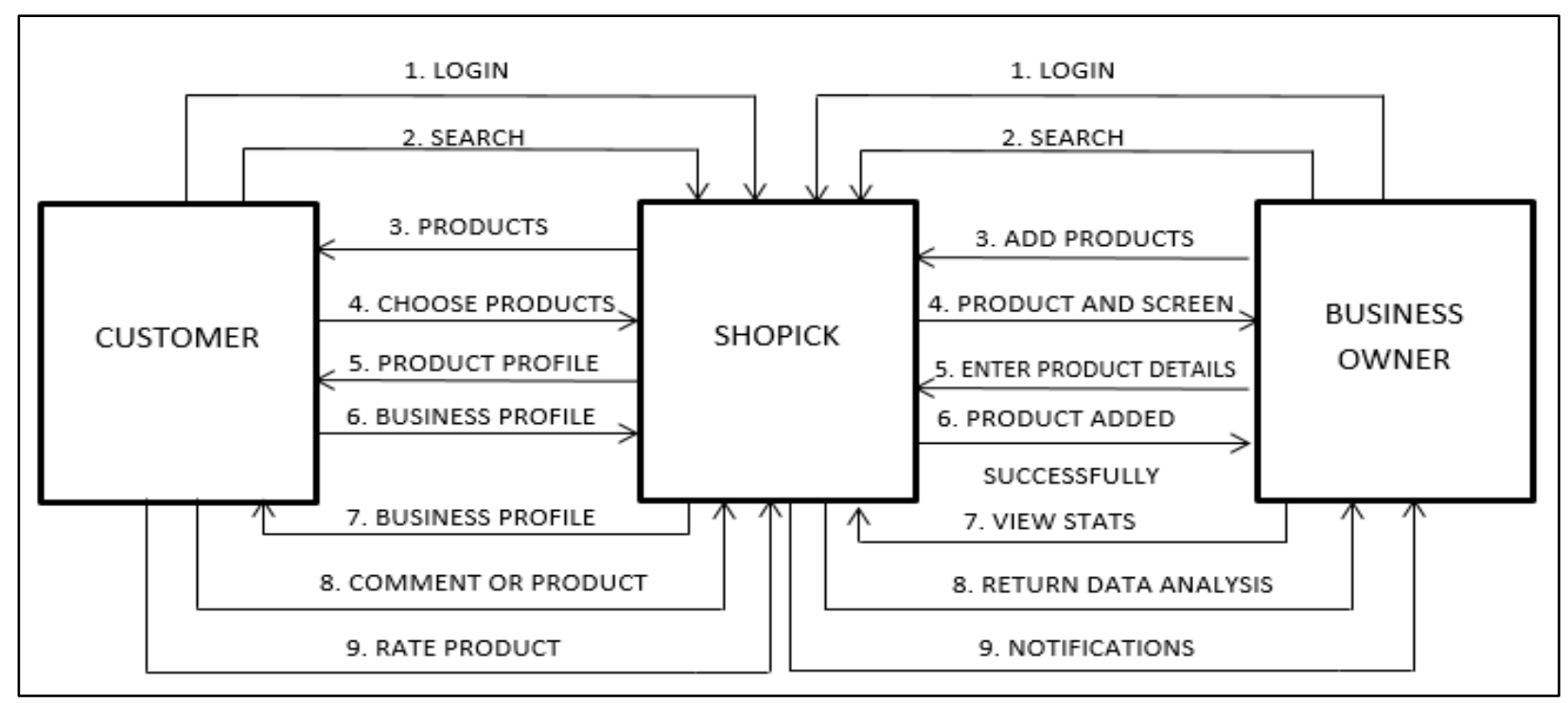

Fig. 9 System Context Diagram

Journal of Independent Studies and Research Computing Vol 19 Issue 1 January-June 2021 


\section{Business Workflow}

A more detailed and in-depth view of the application is shown in Figure 10, i.e., how it will manipulate customers' sides and the business owners' side.

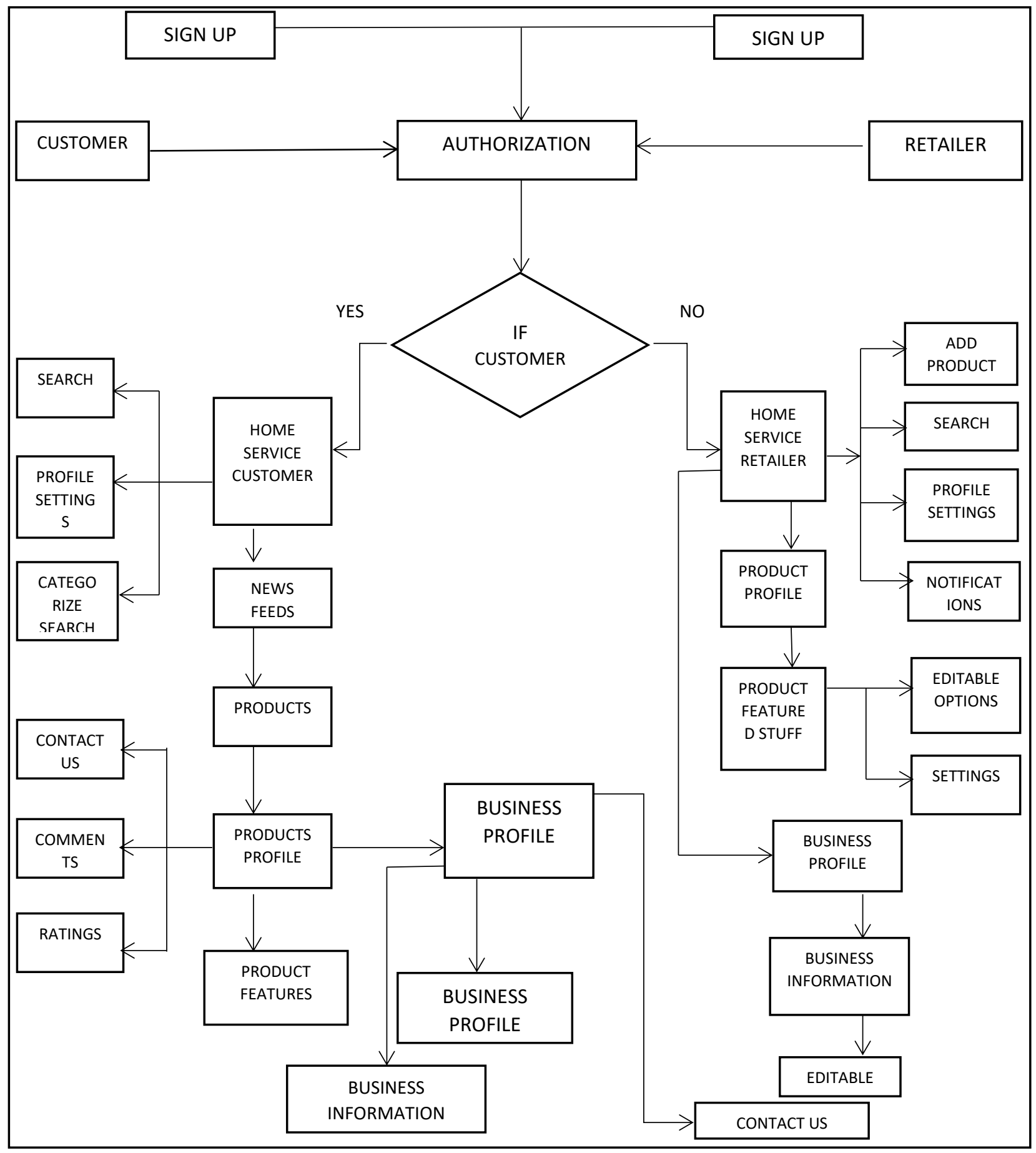

Fig. 10 Business Workflow 


\section{Work Breakdown Structure}

A work breakdown structure states all the goals a project needs to achieve, planned, ordered into various levels, and is presented graphically and vividly.

Basically, the WBS defines the "what" of the project. All you need to attain in the project is shown and revealed in a single, easy-to-understand chart. The purpose of this plan is to break down complex and compound activities into reduced, more management elements.

The Work Breakdown Structure of the project is shown in Figure 11.

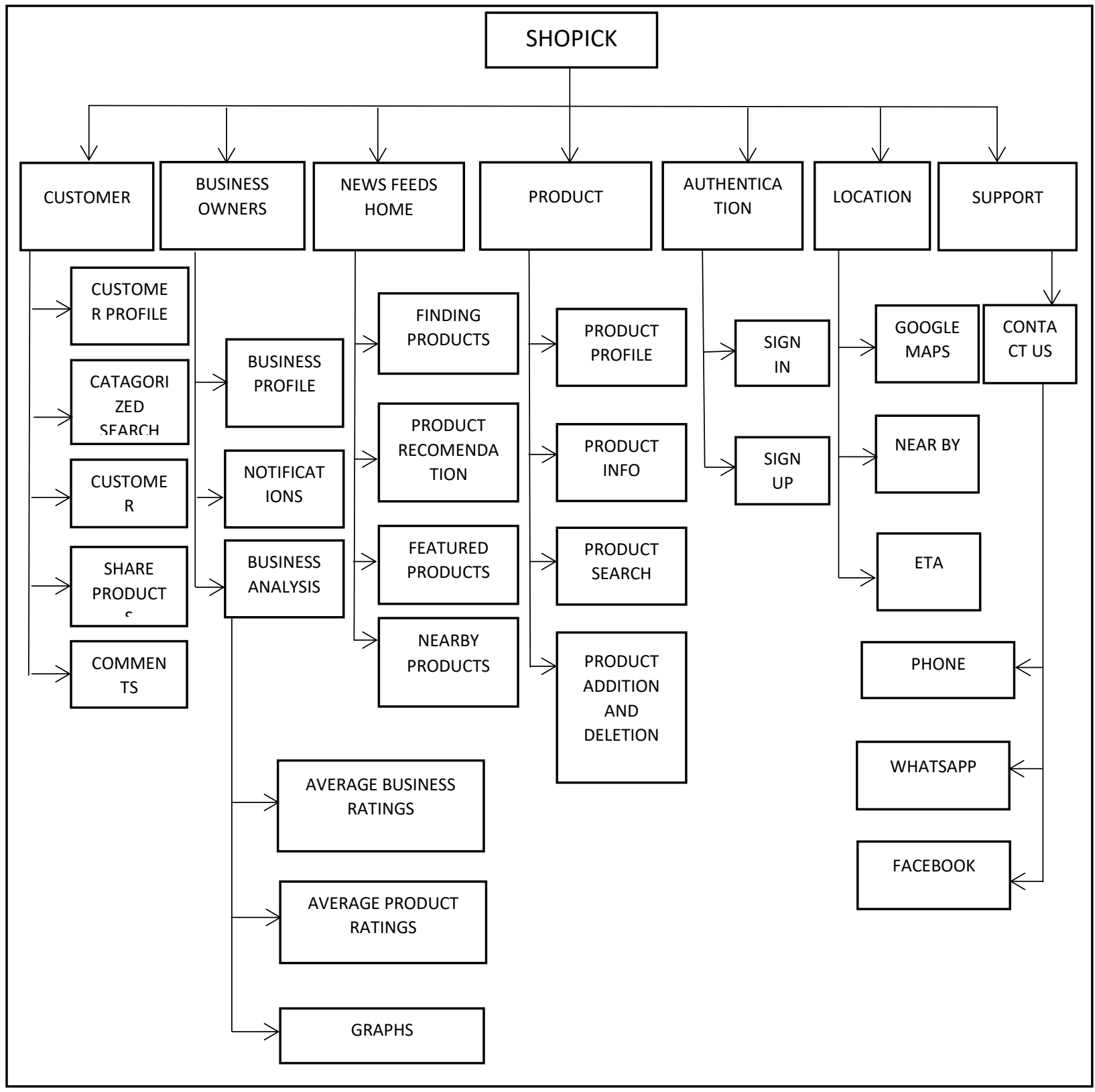

Fig. 11 Work Breakdown Structure 


\section{E. Actor Use-Case Diagram}

A use case diagram show in figure is a diagram that shows the relationships among actors' use-case within a system.

Use case diagrams are often used to:

- Deliver an outline of all or fragments of the user's requirements for a system or organization in the form of a critical prototypical or a business model.
- Communicate the scope of a development of the project.

- Model and translate your analysis of user's requirements or needs in the form of a system use-case model.

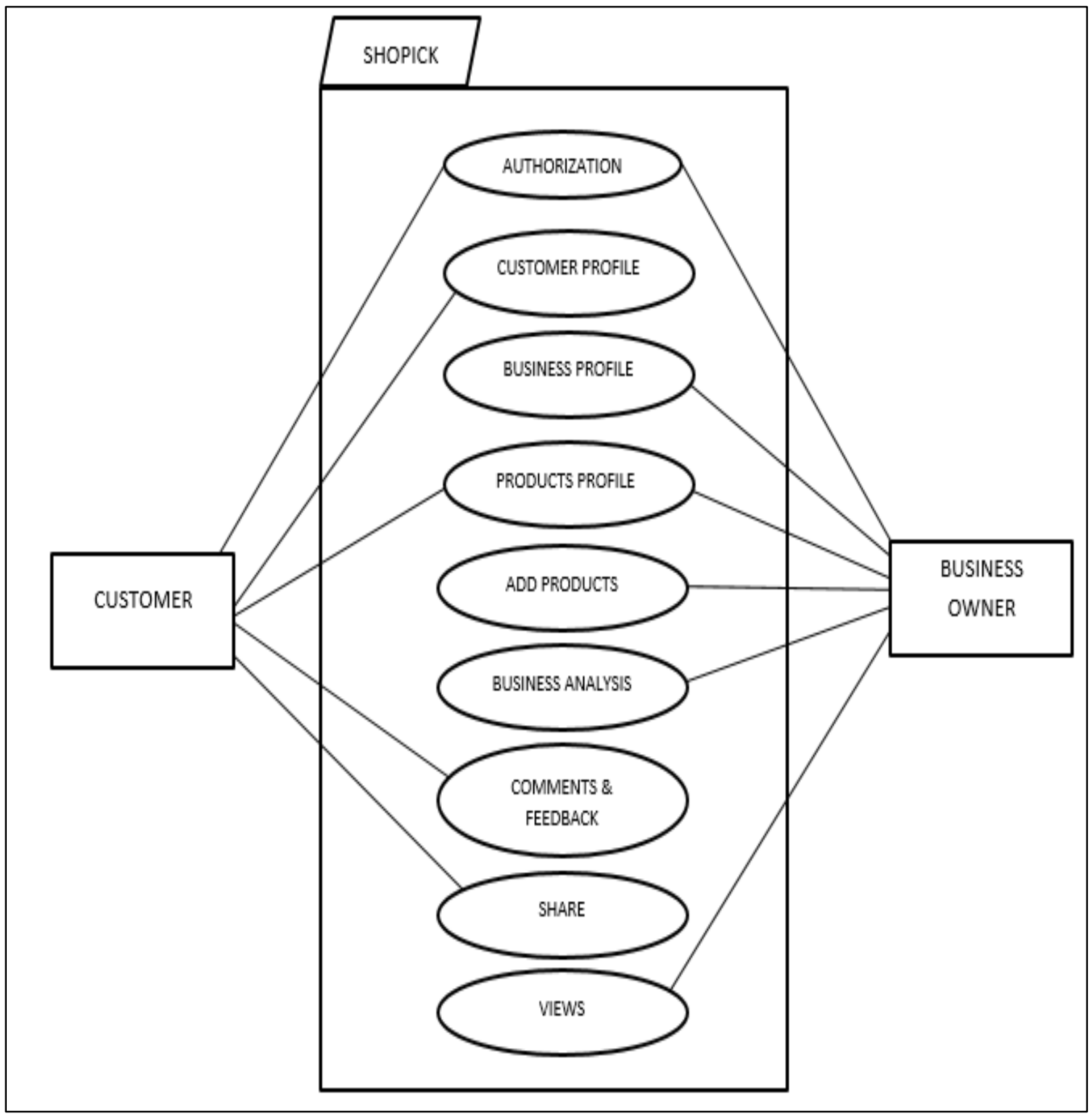

Fig. 12 Actor Use Case Diagram 


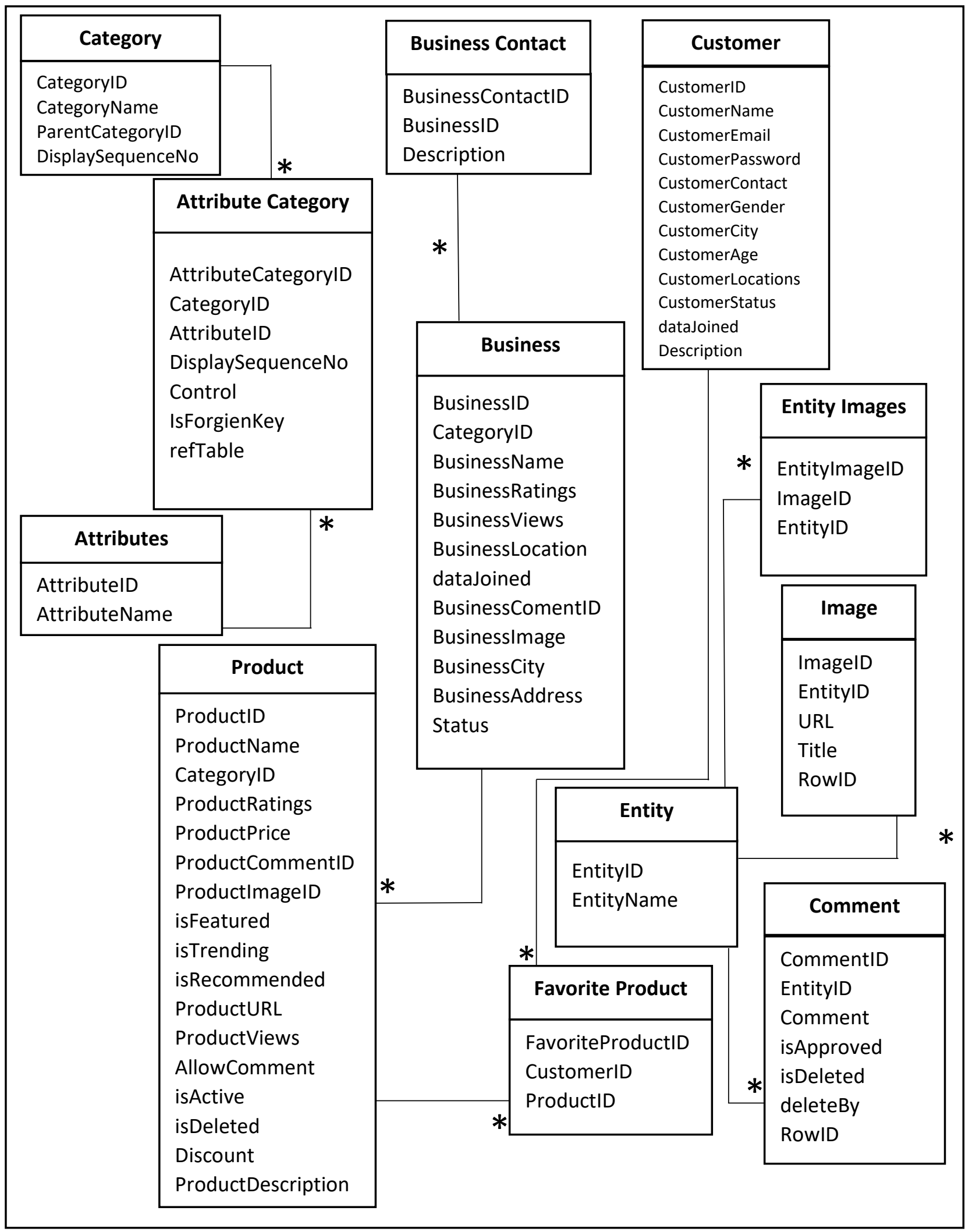

Fig. 13 Entity Relationship Diagram 


\section{RESULTS}

The results of the application are shared along with the User Interfaces:

\section{A. Customer Login}

In the figure 14 given below provided is the Customer Login page in which the customer is already registered on the website. The website will allow the customer, after verification, to $\log$ in to the website.

After Login, the user will access the website's modules, including Personal Customer Profile, Product Profile, and the user can also give feedback and reviews for the product and owner.

The customer can share the website further with other users to help gain a boost for the owner and product sales.

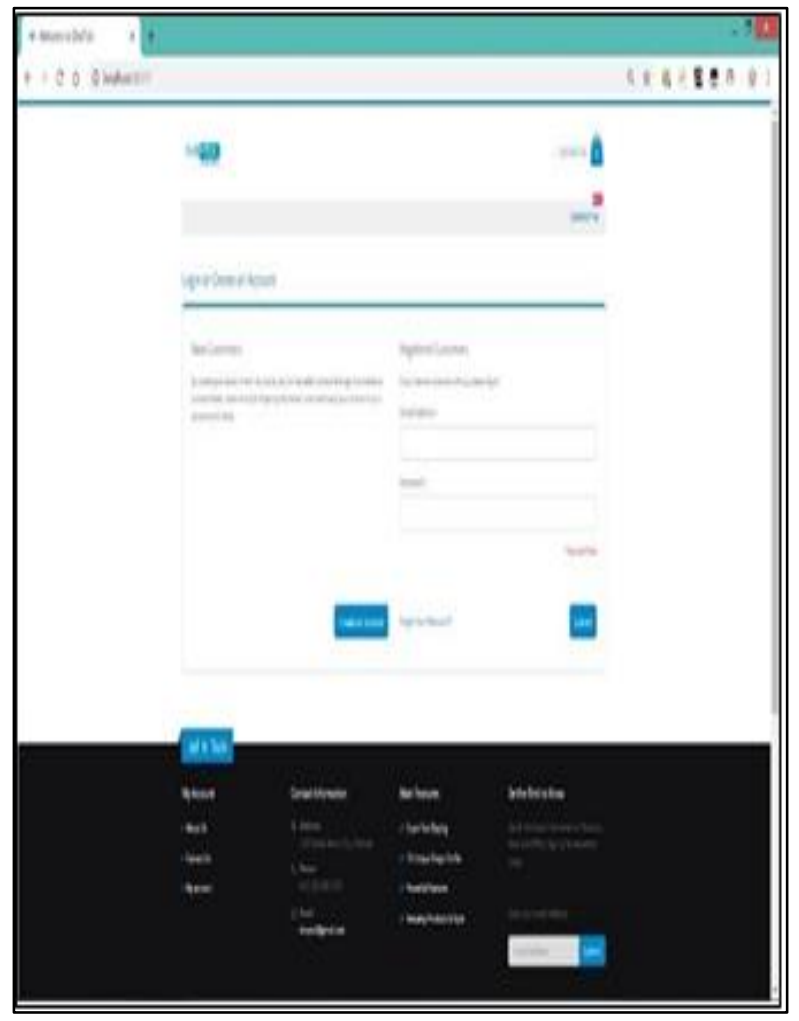

Fig. 14 Customer Login

\section{B. Customer Register}

Figure 15 illustrates about the interface that requires all of the customer's information. For future interest, the user will need to register on the website.

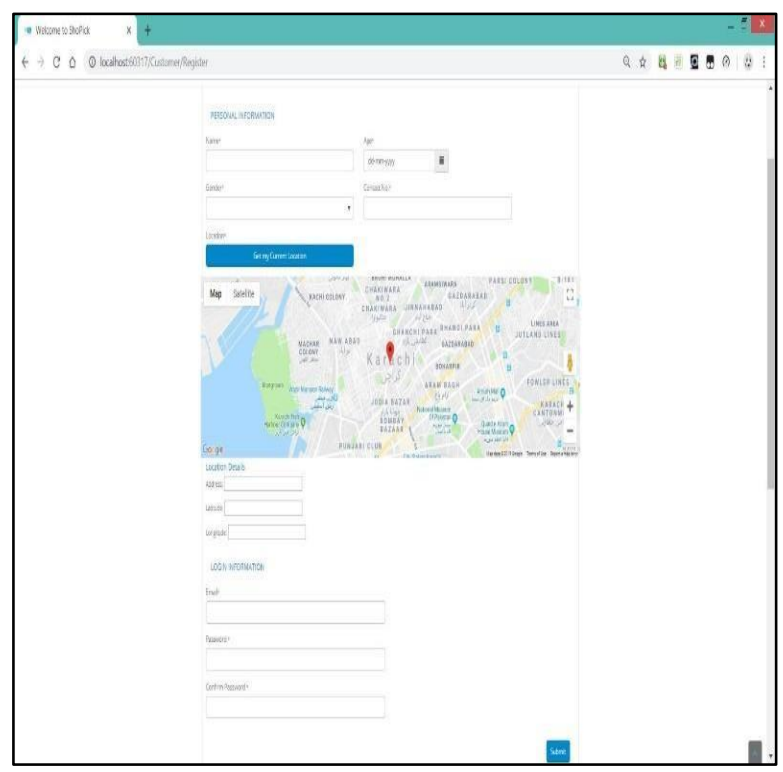

Fig. 15 Customer Register

\section{Homepage}

The customer will view the website's Homepage after registering, as depicted in Figure 16 below. Customers will be able to use the Homepage to track down and obtain product recommendations and deals in their local area.

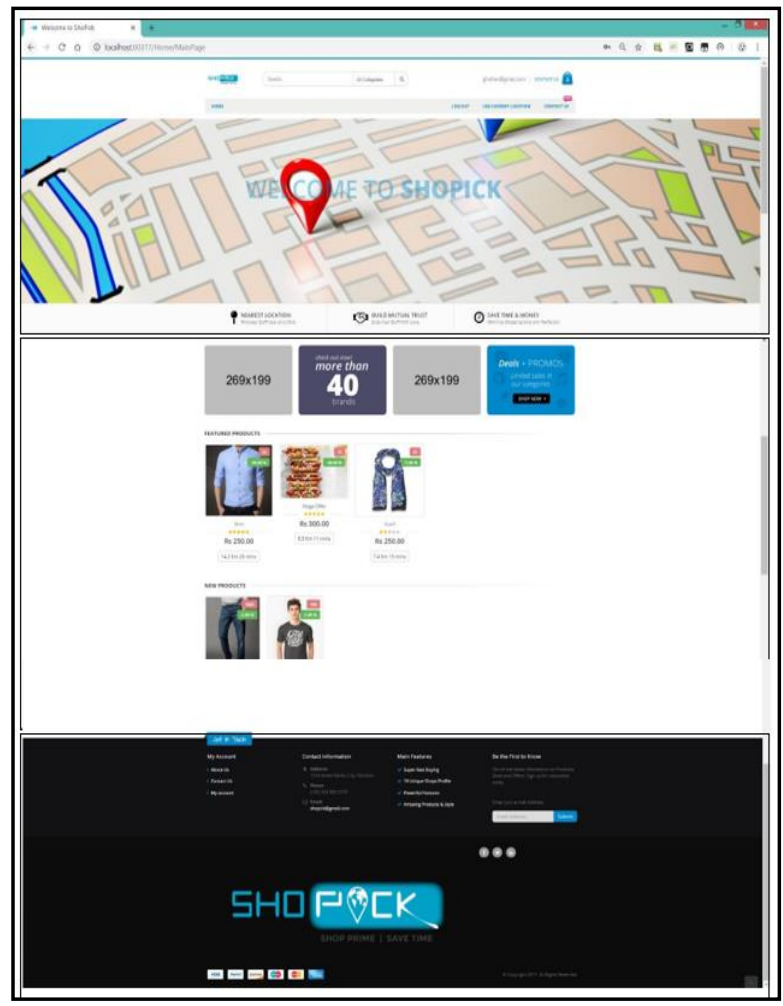

Fig. 16 Homepage 


\section{Product Details}

Figure 17 depicts the user interface for seeing the product's information and description. Which will provide you all of the information you need about the product.

It might include information such as the price, color, and size of the shirt the customer is purchasing, as well as if the product is in stock or not.

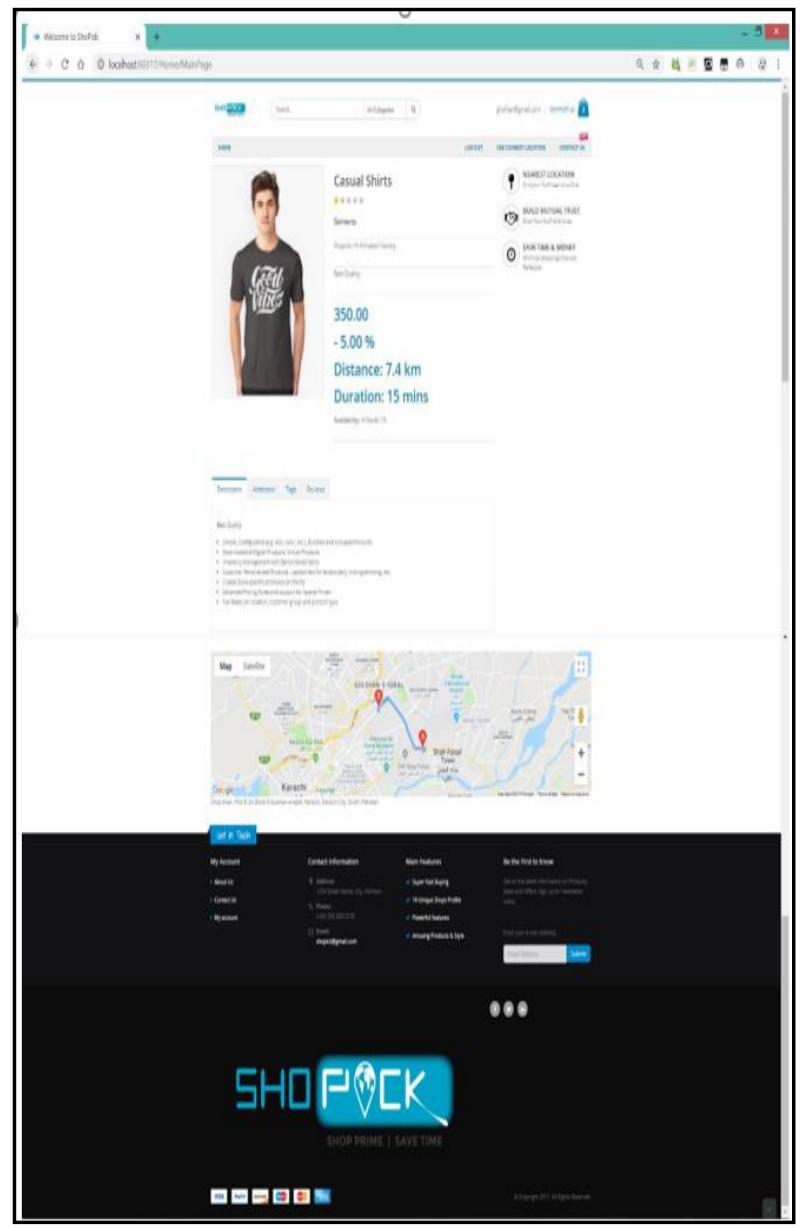

Fig. 17 Product Details

\section{E. Product Search}

The user will be able to able to search the product through the interface shown in Figure 18. Given below.

The product search feature will provide the customer with the product the user will be searching for or might want to check details.

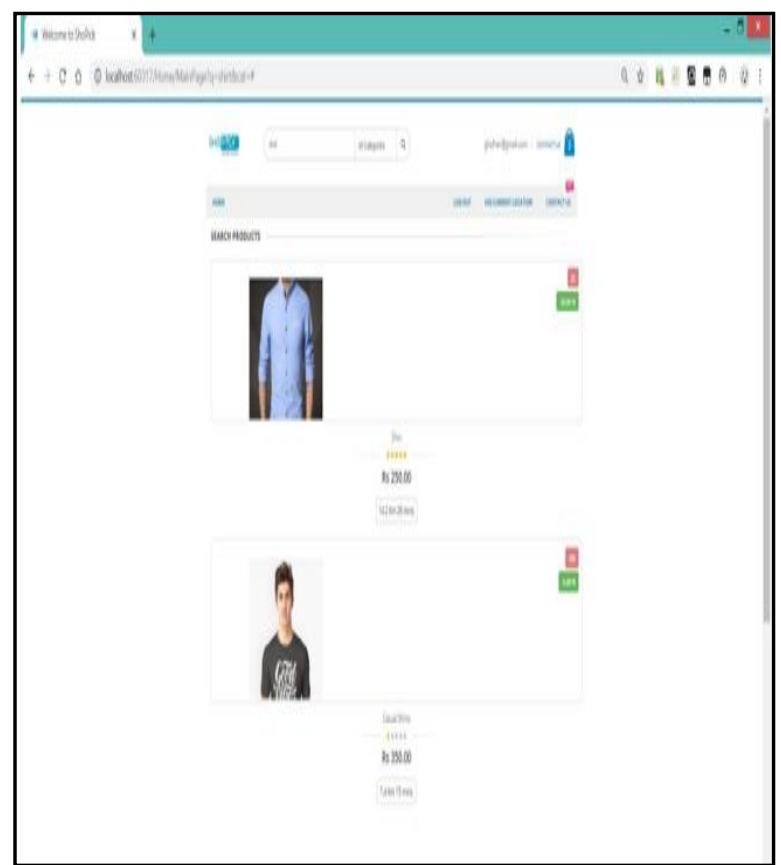

Fig. 18 Product Search

\section{CONCLUSION}

Shopick provides solutions for both the local business owners and customers. Local business owners will get an opportunity to advertise their products and contact the customers' reach or end-users by registering to our application.

On the other hand, the customers would be able to search products according to their vicinity or neighborhood. The search results would be filtered and sorted so that the products available near the customers' area or neighborhood would appear first with routes and Estimated Time of Arrival (ETA). So, the application is basically filling out the gap between customers and the local business owners

\section{ACKNOWLEDGEMENT}

We are overwhelmed in all humbleness and gratefulness to acknowledge our depth to all those who have helped us to put these ideas together, well above the level of simplicity and into something concrete. We would like to express our special thanks of gratitude to our respective universities' administrations for their extensive support in helping and facilitating us in carrying out the research work so diligently. Any attempt at any level can't be satisfactorily completed without our parents, family, and friends' support and patience. A special thanks to Dr. Eiad for his unconditional support and guidance throughout writing this paper. We would like to extend our gratitude towards our support team, who helped us gather information, collect data, and perform research during this paper. Finally, each author of this paper owns a thankfulness and praise for the other 
authors for their kind support, timely correspondences, even as we all were geographically apart, making the research unique.

\section{REFERENCES}

[1] Shahrzad Shahriari, Mohammadreza Shahriari, Saeid Gheiji, Ecommerce and its Impact on Global Trend and Market, University College of Business \&Management Osmania University, Hyderabad, India, Vol.3(ISS.4): April 2015.

[2] Nazmun Nessa Moon, Shaheena Sultana, Fernaz Narin Nur \& Mohd. Saifuzzaman, A Little Review of the Trend of Electric Commerce in Bangladesh Perspective, Daffodil International University, Volume 17 issue 3 version 1.0 the year 2017

[3] R. Tamilarasi, Dr. N.Elamathi, E-commerce-BusinessTechnology- Society, International Journal of Engineering Technology and Management Research, vol.4 (10), 33-41

[4] Gunasegaram, A., et al. "E-commerce and its impact on operations management. "International journal of production economics 75.1 (2002): 185-197.

[5] Subramani, Mani, and Eric Walden. "The impact of e-commerce announcements on the market value of firms." Information Systems Research 12.2 (2001): 135-154.

[6] Schafer, J. Ben, Joseph A. Konstan, and John Riedl. "Ecommerce recommendation applications." Applications of Data Mining to Electronic Commerce. Springer US, 2001.115-153.

[7] Daniel, Elizabeth, and Hugh Wilson. "Adoption intentions and benefits realized: a study of e-commerce in UK SMEs." Journal of Small Business and Enterprise Development 9.4(2002): 331348.

[8] Eastin, Matthew S. "Diffusion of e-commerce: an analysis of the adoption of four e-commerce activities." Telematics and informatics 19.3 (2002): 251-267.

[9] F. J. Riggins, "A Framework for Identifying Web-Based Electronic Commerce Opportunities," Journal of Organizational Computing and Electronic Commerce, 1999

[10] E. Rhodes, R. Carter, "Electronic Commerce technologies and Changing Product Distribution," International Journal of Technology Management, 1998

[11] Kalakota, Ravi and Andrew B. Whinston, "Electronic Commerce: A manager's Guide," Addison Wesley Longman, Inc, 1997.

[12] Smith Dayle, "The E-Business Book: A Step-by-Step Guide to ECommerce and Beyond," Princeton: Bloomberg Press, 2001.

[13] N. S. Al-Jahwari, M. F. Khan, G. K. Al-Khalbani \& S. S.AlKhansouri, "Factors Influencing Customer Satisfaction Of Online Shopping In Oman -Youth Perspective", Humanities and Social Science Reviews, vol. 6, pp. 64-73, October 2018.

[14] A. SHATAT, "Factors Affecting the Adoption and Usage of online Services in Oman", Journal of Internet Banking and Commerce, vol. 22, January 2017.

[15] H. K. AL-Shukri, "Factors Influencing Online Shopping Intention: A study Among Online Shoppers in Oman", International Journal of Academic Research in Business and Social Sciences, vol. 9, pp. 691-709, April 2019.

[16] Chen, Q., Clifford, S.J. and Wells, W., "Attitude Toward the Site: New Information”, Journal of Advertising Research, Vol. 42, No. 2: 33-45, 2000.

[17] Avinash B.M.1, Akarsha B.M.2, Big Data Analytics for ECommerce - Its Impact on Value Creation, International Journal of Advanced Research in Computer and Communication Engineering, Vol. 6, Issue 12, December 2017

[18] M. Nick Hajli, A study of the impact of social media on consumers, International Journal of Market Research, Vol. 56, issue 3
[19] Dr. Rizwana Bashir, Irsa Mehboob, Waqas Khaliq Bhatti, "Effects Of Online Shopping Trends On Consumer-Buying Behavior: An Empirical Study Of Pakistan", Journal of Management and Research, Volume 2 Number 22015

[20] Helena Alves, Cristina I. Fernandes, Mario Raposo, "Social Media Marketing: A Literature Review and Implications: Implications Of Social Media Marketing”, Journal of Psychology and Marketing 33(12):1029-1038, December 2016. 